
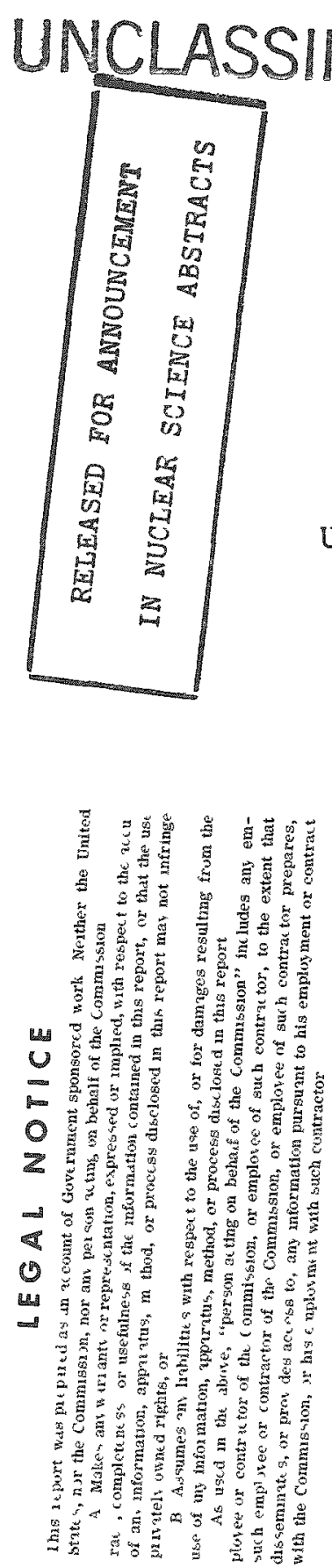

NMI-7018

NUCLEAR TECHNOLOGY - MA TERIALS

(M-3679, 28th. Ed.)

\section{Thoria Dispersion in Uranium}

I.C. 1.00; MN -50

\section{CSEM PREES}

R. W. Anderson

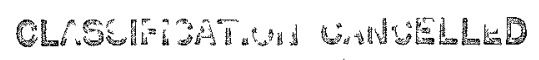

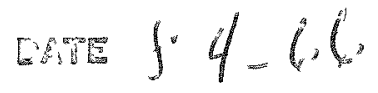

March 25, 1963

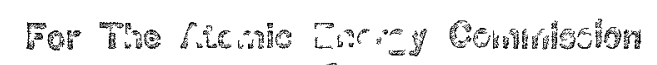

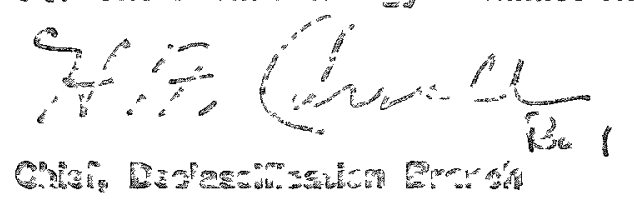

Nuclear Metals, Inc.

West Concord, Massachusetts

Agreement No. 1 under Append ix "C"
Master Terms and Conditions
dated October 1, 1961, NMI-USAEC

A. R. Kaufmann

Technical Director

\section{RESTRAGHED DATA}

This doevment contains restricted data as defined in the Atomic Energy-Act of 1954. Its transmittal or the disclosure of its contents in any manner to an unauthorized person is prohibited.
This document is

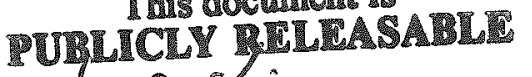

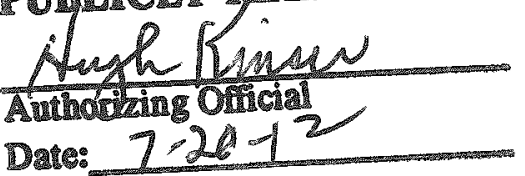




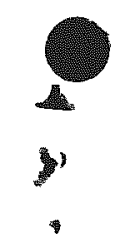

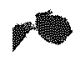

-

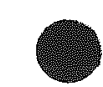




\section{DISCLAIMER}

This report was prepared as an account of work sponsored by an agency of the United States Government. Neither the United States Government nor any agency Thereof, nor any of their employees, makes any warranty, express or implied, or assumes any legal liability or responsibility for the accuracy, completeness, or usefulness of any information, apparatus, product, or process disclosed, or represents that its use would not infringe privately owned rights. Reference herein to any specific commercial product, process, or service by trade name, trademark, manufacturer, or otherwise does not necessarily constitute or imply its endorsement, recommendation, or favoring by the United States Government or any agency thereof. The views and opinions of authors expressed herein do not necessarily state or reflect those of the United States Government or any agency thereof. 


\section{DISCLAIMER}

Portions of this document may be illegible in electronic image products. Images are produced from the best available original document. 
TABLE OF CONIENTS

Page No.

ABSTRACT

7

$\begin{array}{ll}\text { I. INTRODUCT ION } & 8\end{array}$

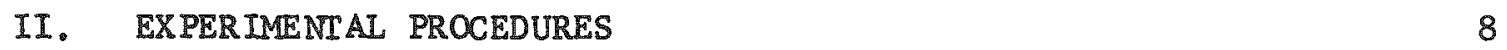

III. RESULTS 18

$\begin{array}{lr}\text { IV. CONCLUS IONS } & 10\end{array}$

$\begin{array}{ll}\text { V. FIGURES } & 11\end{array}$ 


\section{LIST OF EIGURES}

Page No.

FIGURE 1 - Cross-section of melted couple of uranium with thoriacontaining nickel.

FIGURE 2 - Region 1, unmelted dingot uranium.

FIGURE 3 - Region 2, unmelted thoria-containing nickel.

FIGURE 4 - Region 3, U-Ni eutectic adjacent to unmelted thoriacontaining nickel.

FIGURE 5 - Segregation of thoria in eutectic.

FIGURE 6 - Region 4, bulk of U-Ni eutectic. 
ABSTRACT

In an attempt to disperse thoria uniformly in uranium, uranium was melted in contact with a thoria-nickel master alloy up to $800^{\circ} \mathrm{C}$. The thoria particles were found to have agglomerated and segregated in the $\mathrm{U}-\mathrm{Ni}$. 


\section{UNCLASSIFEE WFDENAL}

I. INIRODUCIION

An experiment was performed to determine whether a uniform dispersion of thoria can be produced in uranium by melting uranium with a master alloy of $7 \mathrm{~V} / 0$ thoria dispersed in nickel. The thorla particles range from 0.01 to 0.5 micron in diameter. To minimize the amount of agglomeration that might occur in the 1 iquid phase, melting was effected up to $800^{\circ} \mathrm{C}$. Evaluation of the melted material showed that the thoria particles segregate and agglomerate in molten $\mathrm{U}-\mathrm{N} i$.

\section{EXIERIMENIAI PROCEDURES}

A uranium cylinder (stock $75-1860$ ), 3/4-inch diameter by 1 -inch long, was placed on top of a cylinder of the thorla-containing nickel (stock 4297-590), 3/4-inch diameter by 1/4-inch long, in a graphite crucible surrounded by a quartz vacuum system in a resistance furnace. The uranium had been plated with $1 \mathrm{mil}$ of nickel to maintain a clean surface during heat ing and to promote melt ing. To achieve melting at minimum temperatures, $800^{\circ} \mathrm{C}$, $60^{\circ}$ above the eutect ic temperature, was chosen for this experiment. Heat ing for 1 hour at $800^{\circ} \mathrm{C}$ led to melting of about two thirds of the metal charge. In a similar run made with ordinary nickel, the metal melted completely.

The melted material was prepared for opt ical metallography by grinding and polishing. For examination by electxon microscopy, necessitated by the small particle size, the specimens were electropolished in an orthophosphoric acid electrolyte for 30 seconds at 25 volts.

\section{RESULTS}

A cross-section of the melled thoria"containing specimen is represented in Fig. 1. This specimen contains the four distinct regions described below: the two unmelted starting materials and the two eutectic regions, which differ in thorla content. The companion sample made with ordinary nickel melted completely and showed the expected eutectic structure.

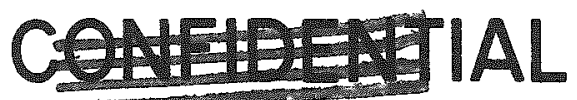

UNCLASSIFIED RESTRICTED DATA 
Region 1, the unmelted uranium

The microstructure of the unalloyed uranium was essentially free of small "second phase" particles except for the expected carbides (Fig. 2$)$.

Region 2, the unmelted thoria-containing nicke1

The unmelted nickel contains a high thoria particle density uniformly distributed (Fig. 3 ).

Region 3, a dark band around the unmelted thoria-containing nicke1 (This material was melted and its external dimensions approximated those of the original nickel section.)

This region is composed of $\mathrm{U}-\mathrm{Ni}$ eutectic and the thoria particles (Fig. 4). As evidenced by the sharp demarcation between Regions 3 and 4 in $i g$. 4, the thoria particles did not mix in the bulk of the molten eutectic lloy. Upon freezing of the thoria-containing region of the eutectic, the thoria was rejected by one of the eutectic components (probably the uraniummich phase), thereby destroy ing the uniform particle distribution (Fig. 5, a and b). In addition to segregating, the thorla showed a tendency to agglomerate.

Region 4 , the bulk of the eutectic material that had melted

This region is also composed of the $\mathrm{U}-\mathrm{Ni}$ eutectic, but is relatively free of the thoria particles observed in the portion of the eutectic melt around the unmelted nickel. Those thoria particles present have segregated into patches (Fig. 6 , and b). 
IV. CONCLUS IONS

(1) Thorla particles do not read1ly mix with molten U-Ni at $800^{\circ} \mathrm{C}$.

(2) The thorla particles tend to agglomerate in molten U-Ni at $800^{\circ} \mathrm{C}$.

(3) During the freezing, the thorla particles are segregated into one of the eutectic components. 


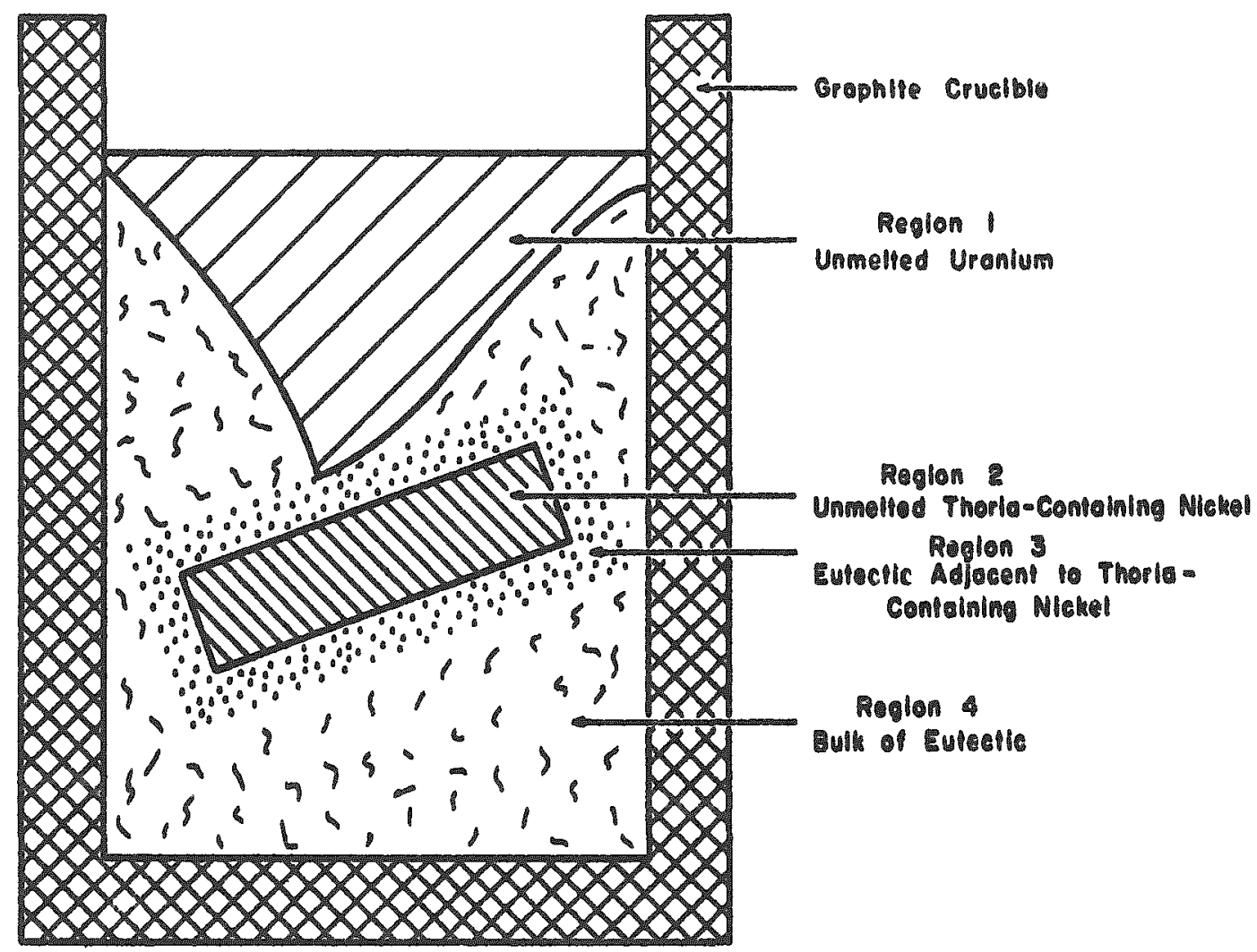

1213. 1 - Crosg-section of melted couple of uranlum with thoria-containing nickel.

Draving No. RA-2505. 


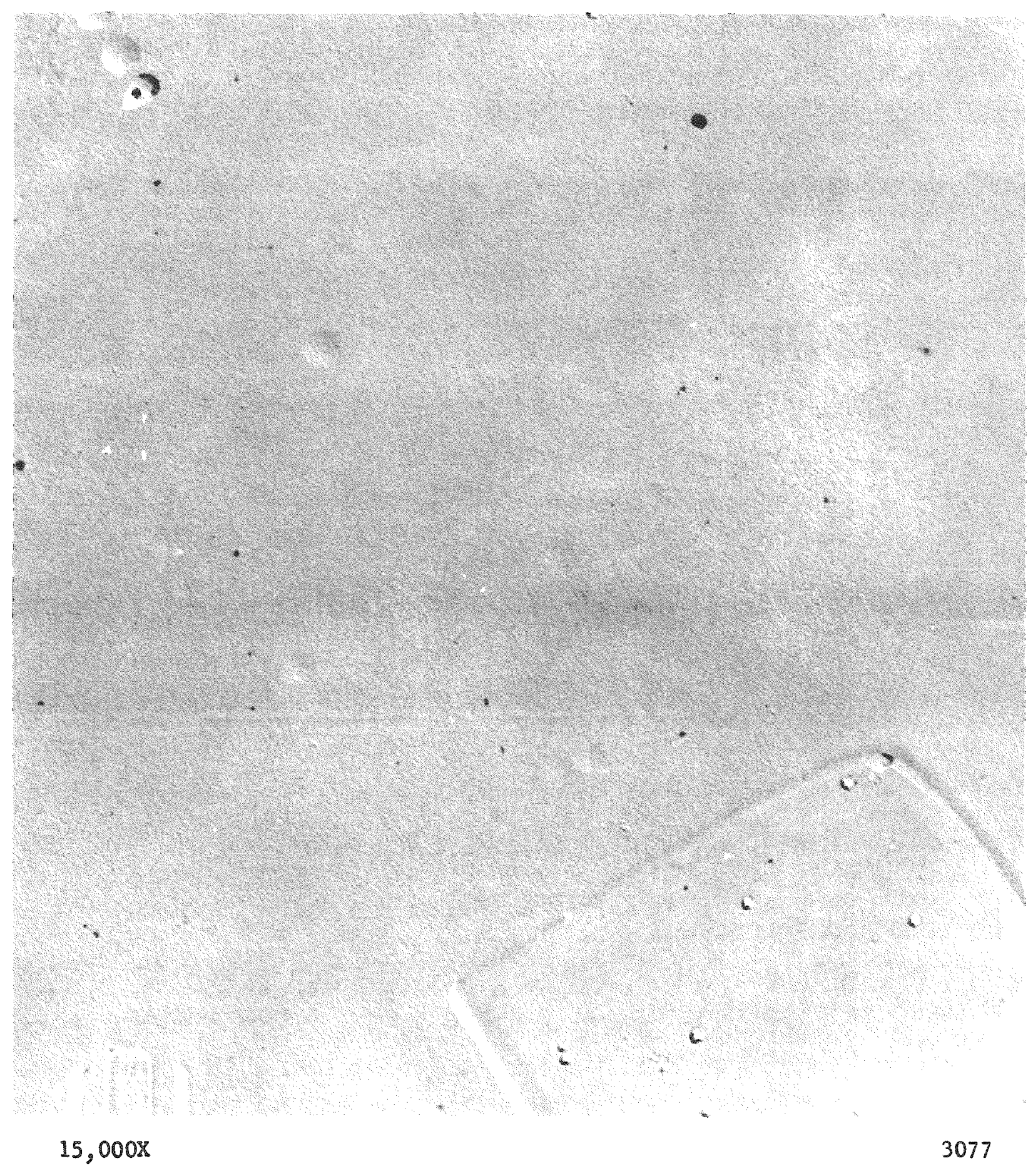

Fig. 2 - Region 1, unmelted dingot uranium. Material is relatively free of "second phase" particles except for carbides (lower right-hand corner).

UNCLASSIFIED 


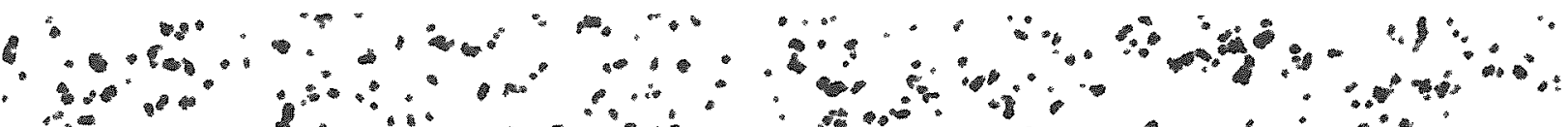

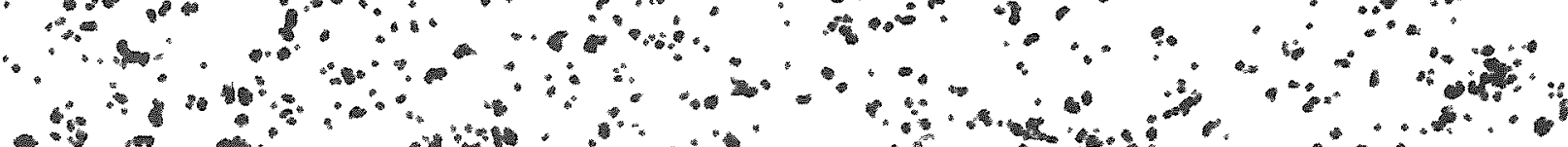

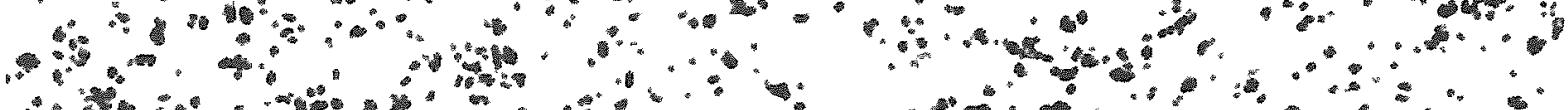

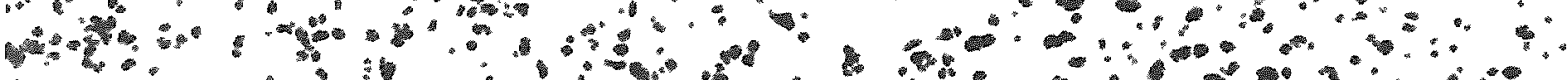

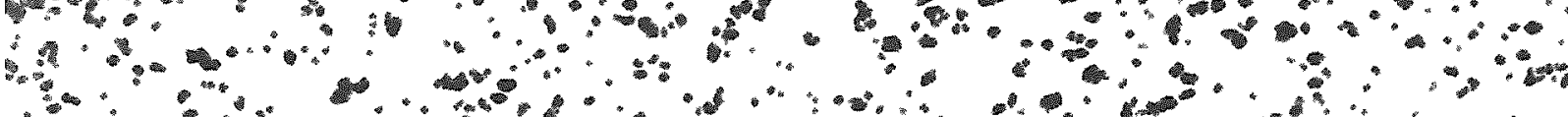

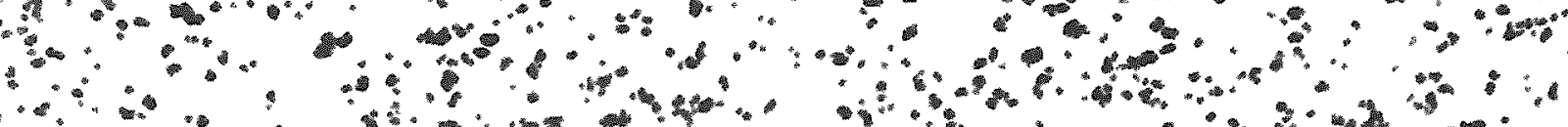

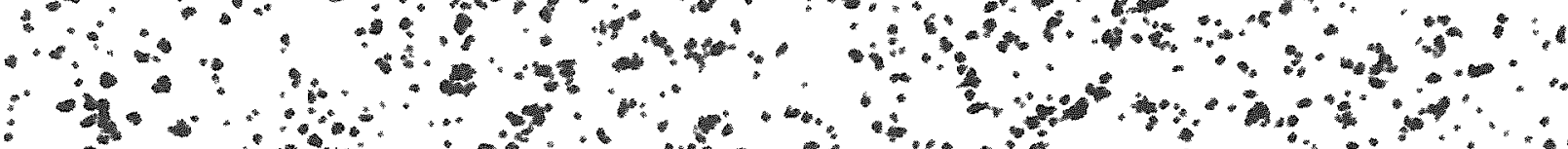

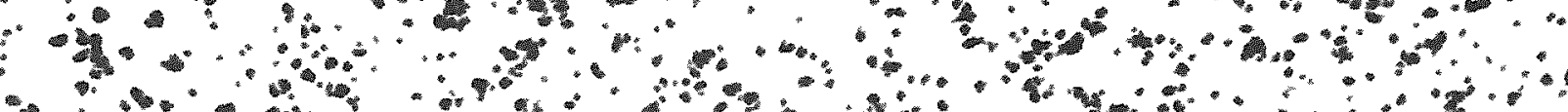

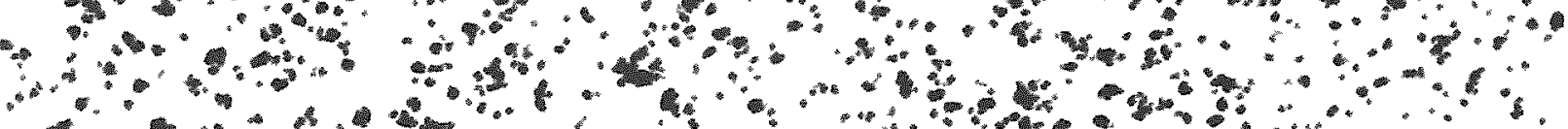

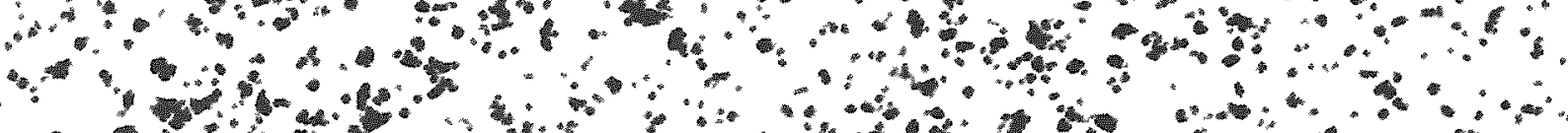

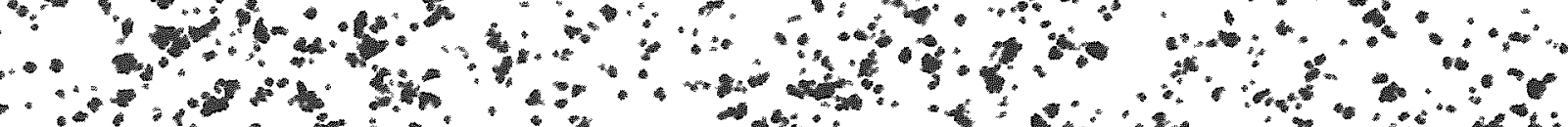

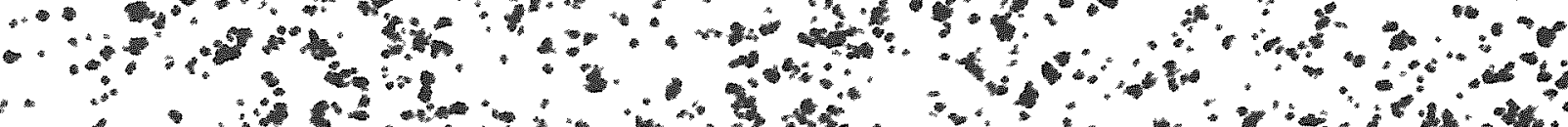
" 2. , l.

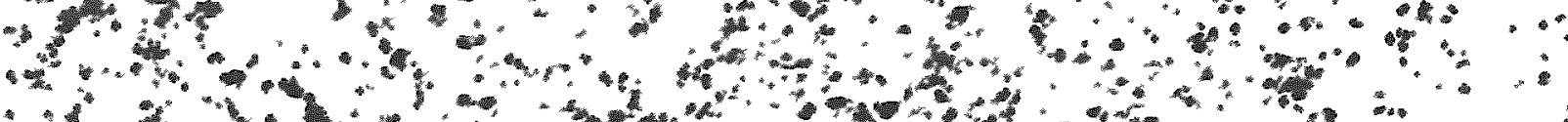

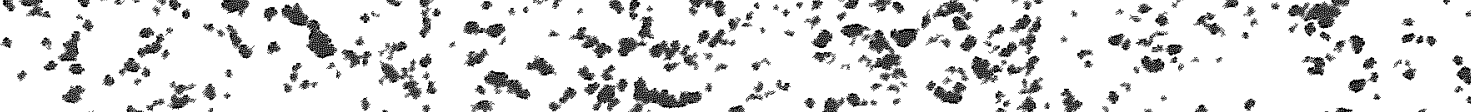

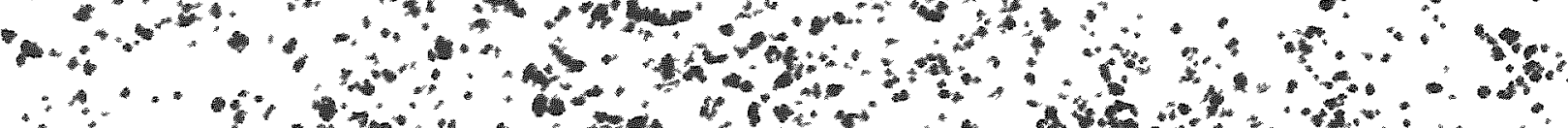
F,

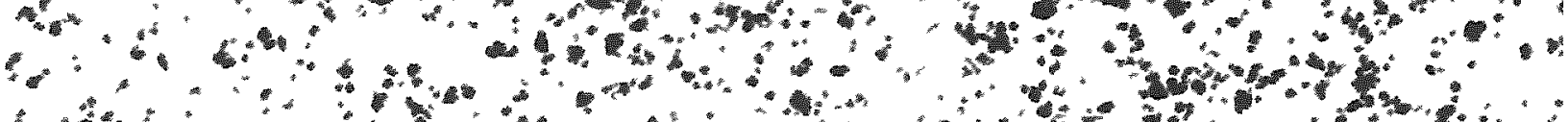

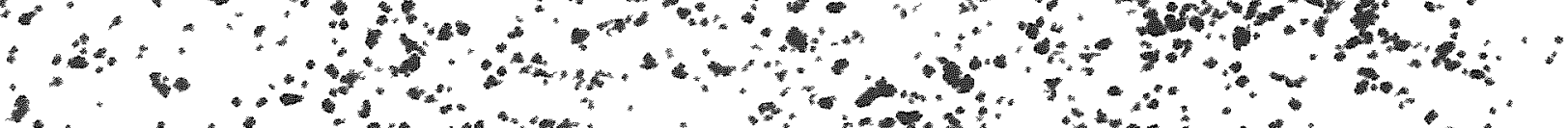
F. ." 6."

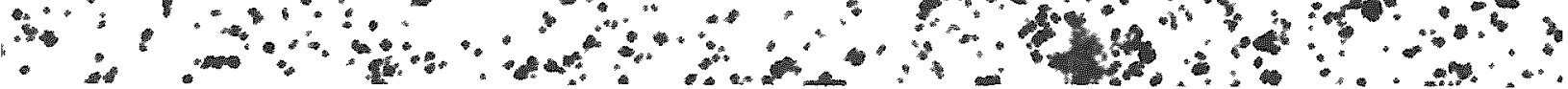
$4000 x$

1200

Fig. 3 - Region 2, unmelted thoria-containing nickel. Thoria particles 0.01 to 0.5 micron in diameter uniformly distributed. 


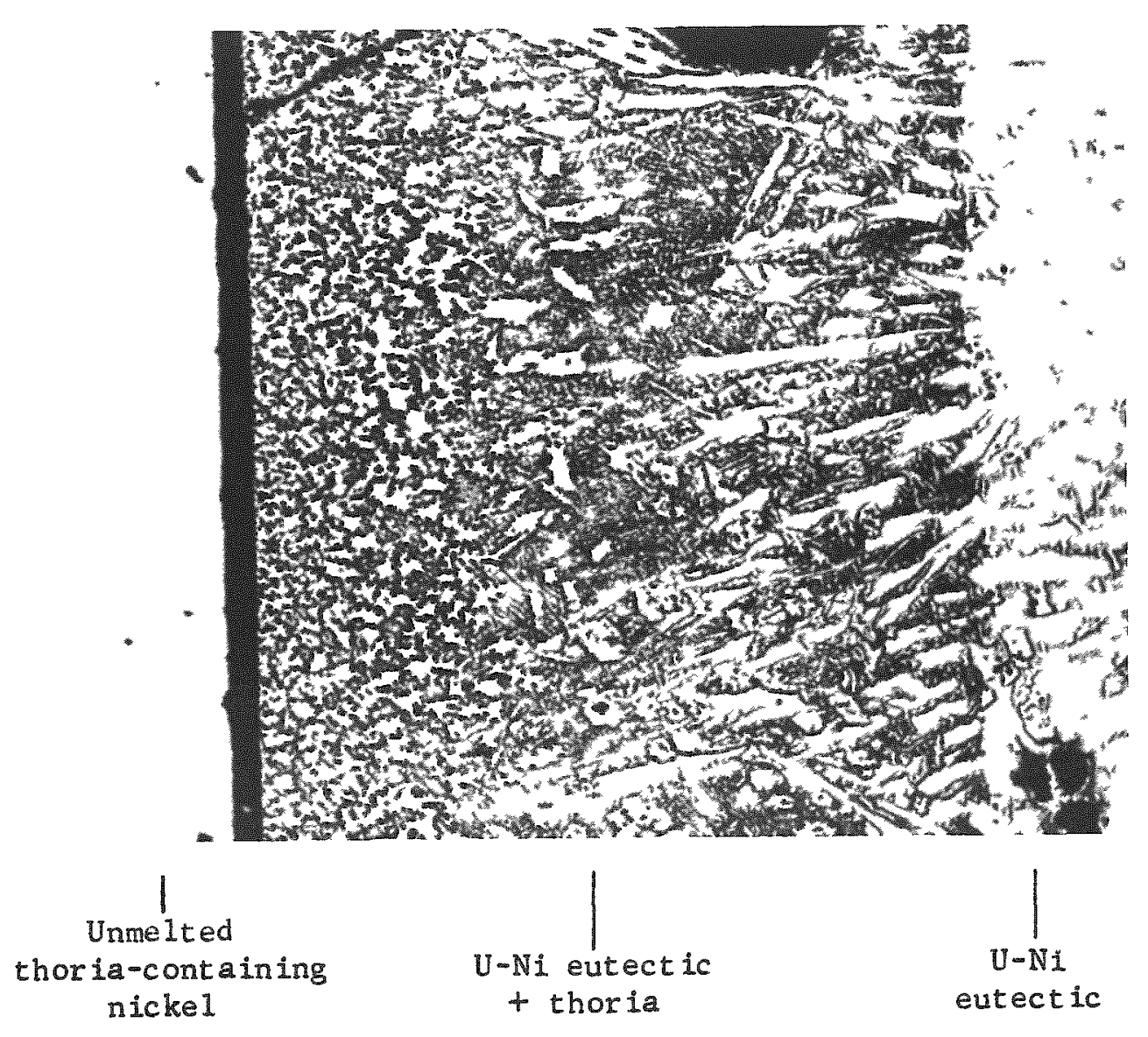

Fig. 4 - Region 3, U-Ni eutectic adjacent to unmelted thoria-containing nickel. 100X. A-4248-a. 


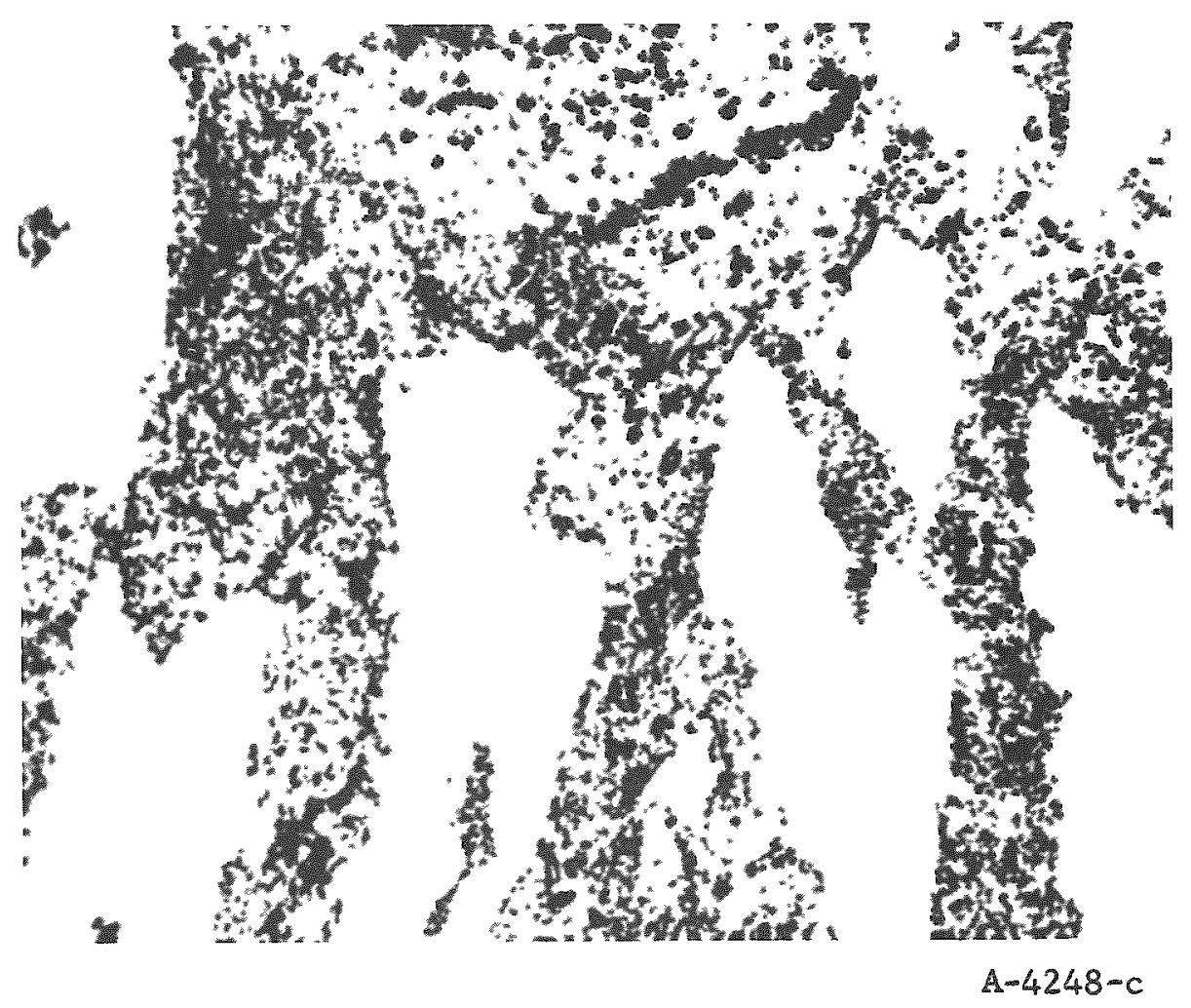

(a) 1000\%。

Fig. 5-Region 3, segregation of thoria in eutectic. 

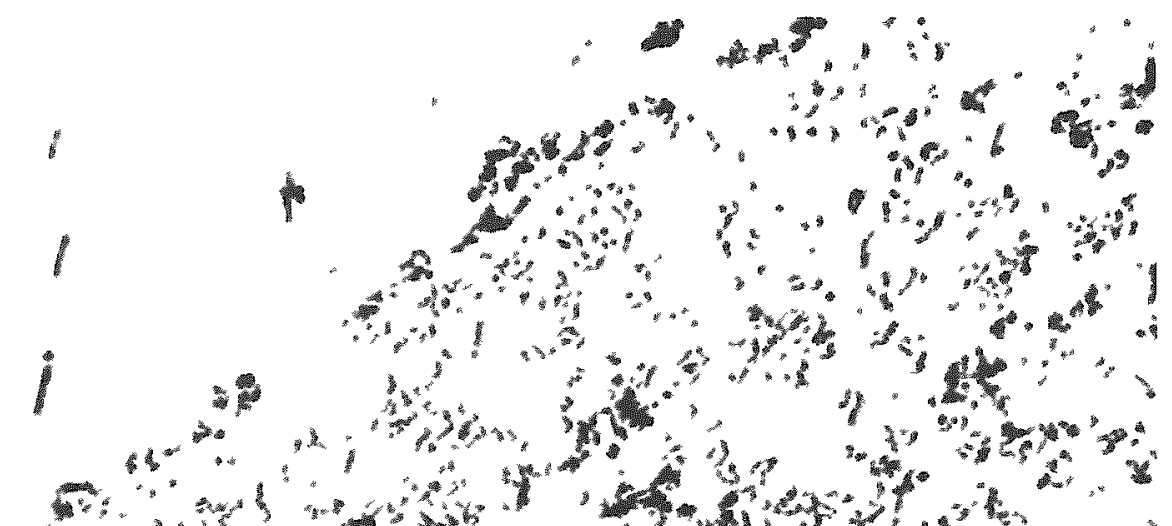

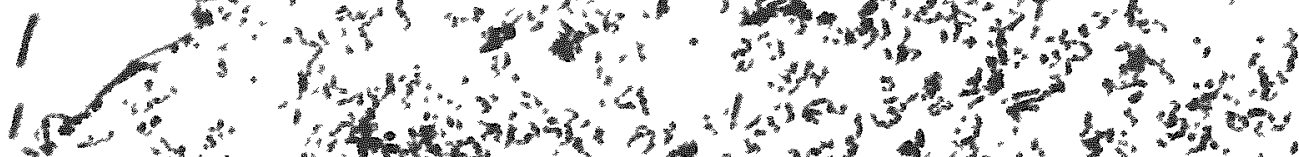

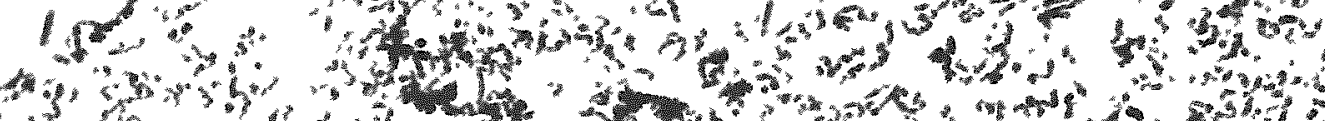
1.3.

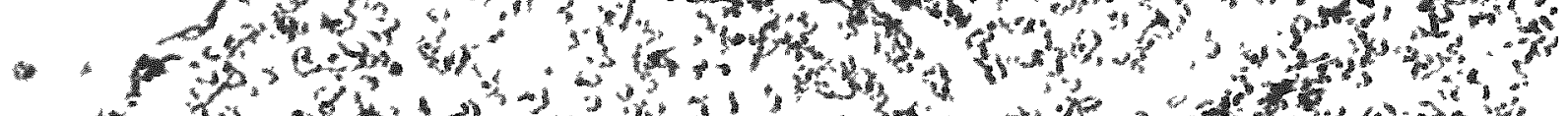
- Io

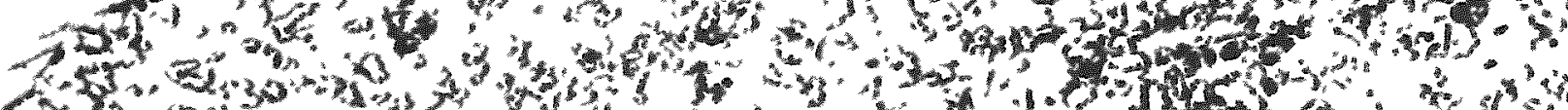

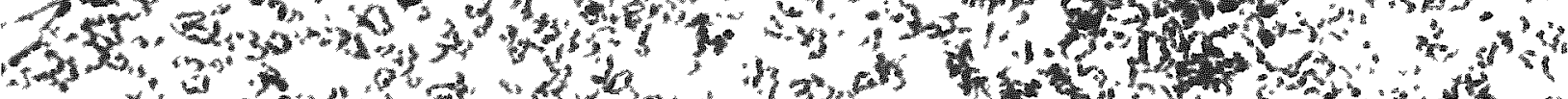

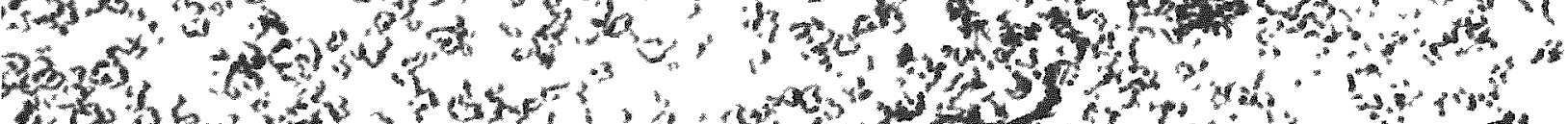
H.

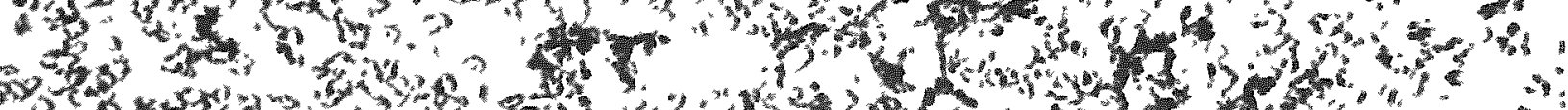

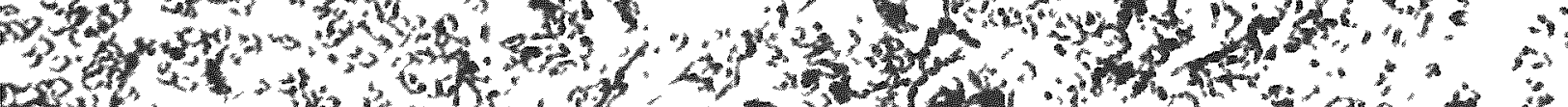
wy.1. Fis. 5.

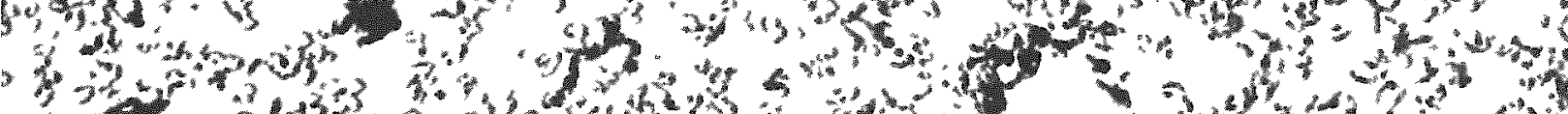

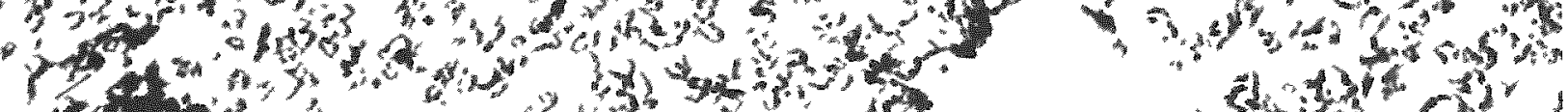

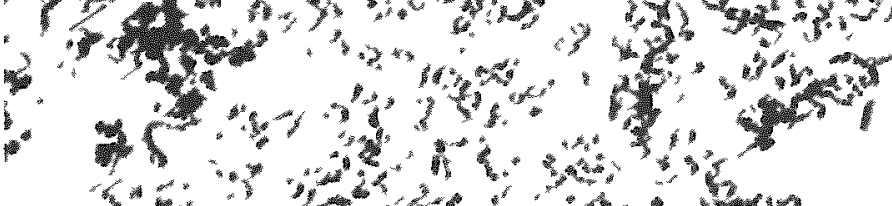
6.5.".

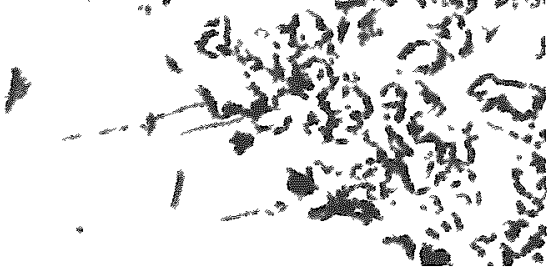

1205

(b) 4000X.

Fig. 5 (continued) 


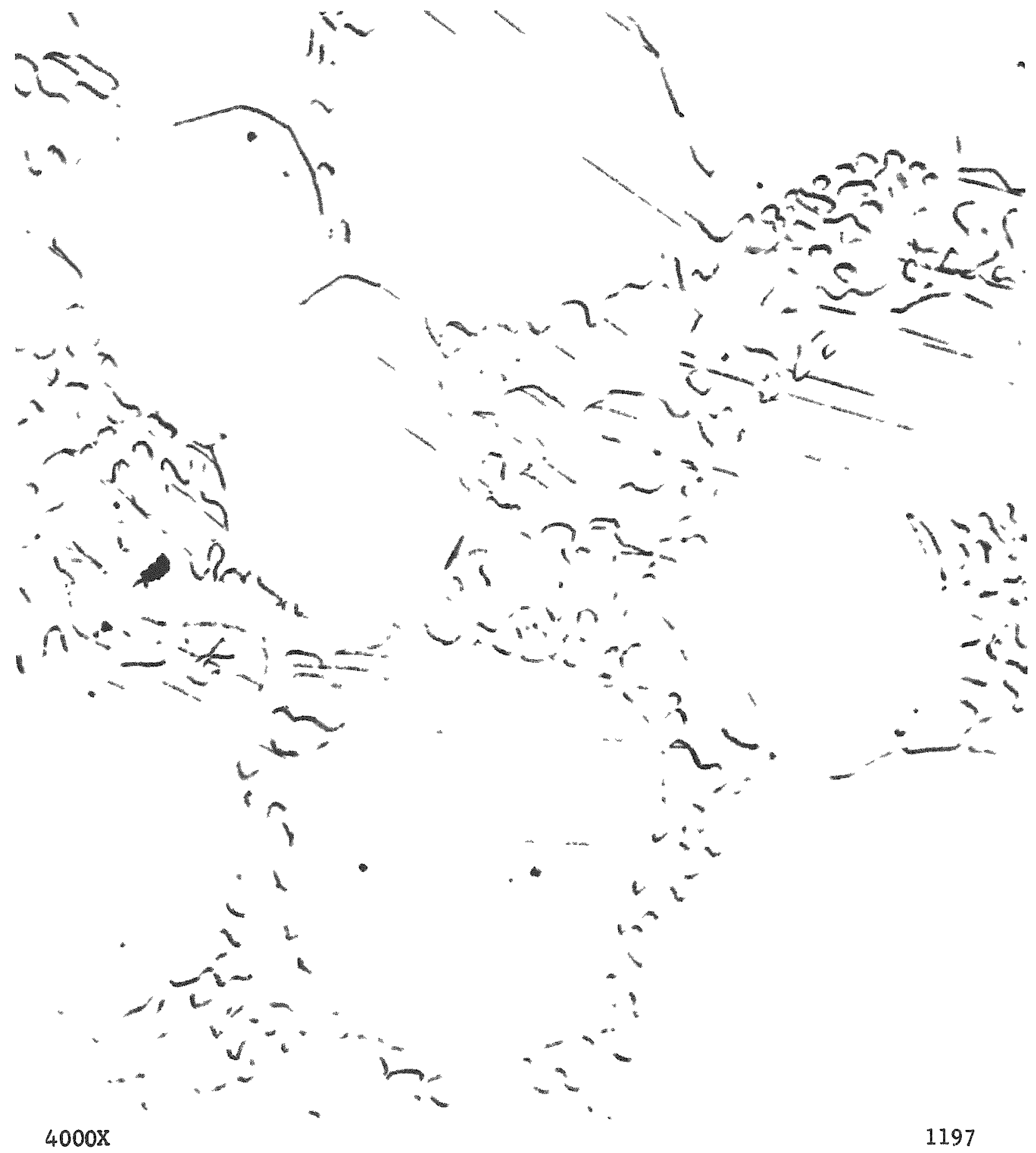

(a) Major portion of Region 4 contains no thoria.

Fig. 6 - Region 4, bu1k of U-Ni eutectic. 


\section{UNCLASSIFIED}

18
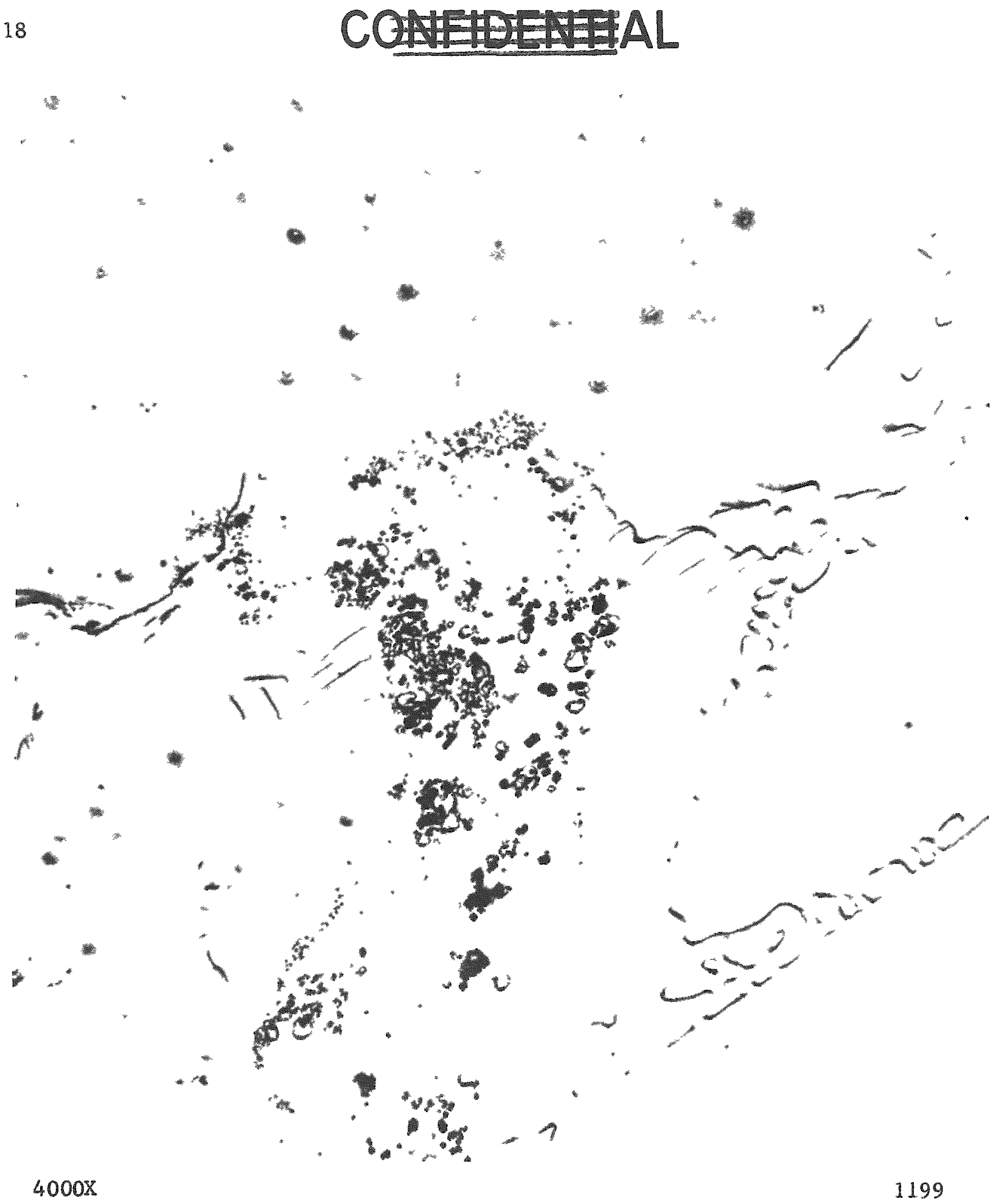

(b) Few thoria particles in isolated patches.

Fig. 6 (continued) 